\title{
WILLIAM H. KILBY
}

\author{
$1881 \cdot 1944$
}

William H. Kilby, Supervisor of Fire Protection, Canadian National Railways's System in Western Canada and a valued member of the Society died suddenly at his home in Winnipeg on March 19, at the age of 62. Death was due to pneumonia. He is survived by his wife, Mrs. Laura S. Kilby; one daughter, Nancy Patricia; one son, Peter; and his father, William Kilby, of Vancouver.

"Bill" Kilby was a familiar figure at Society gatherings since he became a member in April, 1924. His energetic and enthusiastic participation in Society activities are evident in the records of the Society throughout the intervening years. This interest was not unlikely prompted by the misadventure which befell him in the first decade of the century when he was home. steading in the vicinity of Baudette, Minnesota. At that time he had the misfortune to be burned out by a forest fire, losing everything he owned. Shortly thereafter he entered the United States Forest Service as forest ranger and his primary interest since that time has been in forest protection and con. servation. For many years he has served as a Director of the Canadian Forestry Association.

In his span of sixty-two years he had a varied and adventurous career, seeing service in all three branches of the Armed Forces-Navy, Army and Air Force-and participating in the Boxer Rebellion and World War I.

Born at Twickenham, Middlesex, England, in November, 1881, he joined the Middlesex Volunteers in 1898 and served with that regiment until 1900, when he joined the Royal Navy, serving on the China station. At that time he saw action in the Boxer Rebellion. In 1905 he obtained his discharge from the Royal Navy and came to Canada.

In 1906 he went to the United States, but following his period with the United States Forest Service he returned to Canada in 1910 and became a forest ranger at Minnedosa, Manitoba.

On the outbreak of the first Great War he enlisted in the 79th Cameron Highlanders and went overseas with the 43rd Battalion as a lieutenant, serving as signals and machine-gun officer. Later, transferring to the Royal Flying Corps as an observer, he was shot down and wounded in aerial combat. In March, 1917, be obtained his pilot's wings and joined the Royal Naval Air service.

Having passed the age limit for active service in the present war, he joined the Veteran's Guard (reserve) as a private.

"Bill" Kilby will be sincerely missed by the Society as a body and by the individual members, both new and old. 